\title{
Lumbarisation of the First Sacral Vertebra a Rare Form of Lumbosacral Transitional Vertebra
}

\author{
Lumbarización de la Primera Vertebra Sacra: Rara \\ Forma de Una Vertebra de Transición Lumbosacral
}

Mallikarjun Adibatti* \& Asha, K.**

\begin{abstract}
ADIBATTI, M. \& ASHA, K. Lumbarisation of the first sacral vertebra a rare form of lumbosacral transitional vertebra. Int. J. Morphol., 33(1):48-50, 2015.

SUMMARY: In the lumbosacral region, anatomical variations occur with changes in the number of sacral vertebra either by deletion of first sacral vertebra or by the union of fifth lumbar or first coccygeal vertebra with sacrum. Lumbasacral transitional vertebrae (LSTV) is the most common congenital anomalies of the lumbosacral region. It most commonly involves the fifth lumbar vertebra showing signs of fusion to the sacrum known as sacralisation or the first sacral vertebra shows signs of transition to a lumbar configuration commonly known as lumbarisation. Complete transition can result in numerical abnormalities of the lumbar and sacral vertebral segments. Lumbarisation of first sacral vertebra is seen with a very low incidence of $2 \%$. Knowledge of presence of such vertebral variation will be helpful for the clinicians to diagnose and treat patients with low back pain. Although sacralisation of fifth lumbar vertebrae is most commonly seen when compared to lumbarisation of first sacral vertebrae, we report here a case of lumbarisation of first sacral vertebrae for its rarity among the LSTV and clinical implications.
\end{abstract}

KEY WORDS: Vertebrae; Sacrum; Sacralisation; Lumbarisation; Transitional vertebrae.

\section{INTRODUCTION}

The sacrum is formed by the fusion of five sacral vertebras. It is wedge shaped bone present between the two hip bones and takes part in forming the bony pelvis. It is triangular in shape with its upper end or base which articulates with the fifth lumbar vertebra, lower end or apex which articulates with the coccyx and its auricular surfaces articulating with the two hip bones. It has four pairs of ventral and dorsal sacral foramina that communicate with sacral canal. Normally, the sacrum is formed by the fusion of five rudimentary vertebrae. But anatomical variations of the sacrum have been reported like sacralisation of fifth lumbar vertebra and lumbarisation of first sacral vertebra. It commonly involves the fifth lumbar vertebra showing signs of assimilation to the sacrum known as sacralisation or the first sacral vertebra shows signs of transition to a lumbar configuration commonly known as lumbarisation. Lumbarisation of first sacral vertebrae is a very rare lumbosacral transitional vertebral (LSTV) anomaly necessitating the ability to accurately identify and number the affected segment. Awareness of such congenital anomaly is important before any spinal surgery in order to avoid incorrect numbering of vertebrae and consequently prevent wrong level spinal surgery.

\section{RESULTS}

During routine Osteology classes, we observed the articulated skeleton in our department showing partial lumbarisation of the first sacral vertebrae on the left side. The sacrum in this skeleton had only 4 bodies of sacral vertebrae with three distinct ventral and dorsal sacral foramina. It demonstrated partial lumbarisation on the left side with presence of distinct transverse process, while on the right side it was fused with the second sacral vertebrae. The ala formation on the right side was contributed by fused parts of both S1 and S2. While on the left side S2 alone contributed to the formation of ala by enlarging and fanning of its superior surface. The bodies of both vertebrae were completely separated from each other both ventrally and dorsally by presence of distinct intervertebral space (Fig. 1). Lumbar vertebrae were 5 in number and normal in their contour.

On the dorsal surface of the sacrum following observations were made. The lamina of the $\mathrm{S} 1$ was separated completely from S2 with presence of distinct gap between the two. Disc space was clearly seen separating both $\mathrm{S} 1$ and S2. Transverse process was distinctly separated on the left

* Assistant Professor of Anatomy, ESIC Medical College and PGIMSR, K. K. Nagar Chennai, India.

*** Associate Professor of anatomy, ESIC Medical College and PGIMSR, K. K. Nagar Chennai, India. 
side but right side it maintained a small attachment. The articular facets of $\mathrm{S} 1$ and S2 were fused. Lateral to the intermediate crest three dorsal sacral foramina were seen (Fig. 2). Squaring of the upper segment of S1 was seen.

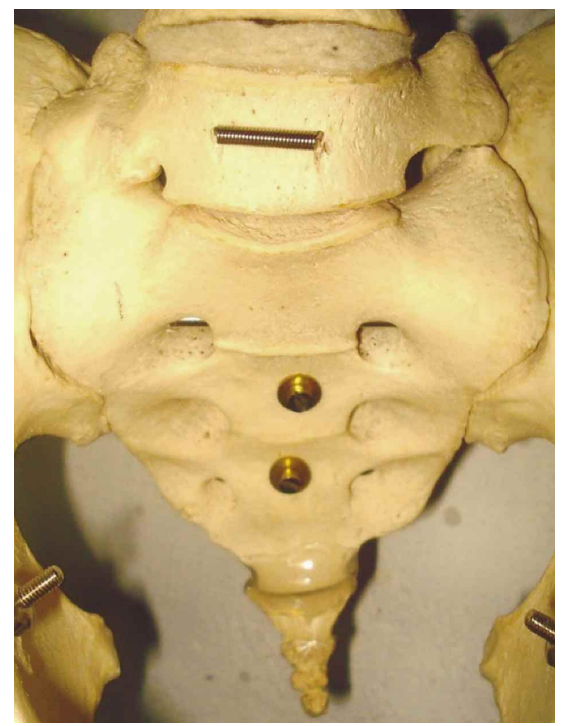

Fig. 1. Ventral surface of sacrum showing Partial Lumbarisation of first sacral vertebrae with presence of distinct disc space between S1 and S2. Sacrum below showing three distinct sacral foramina.

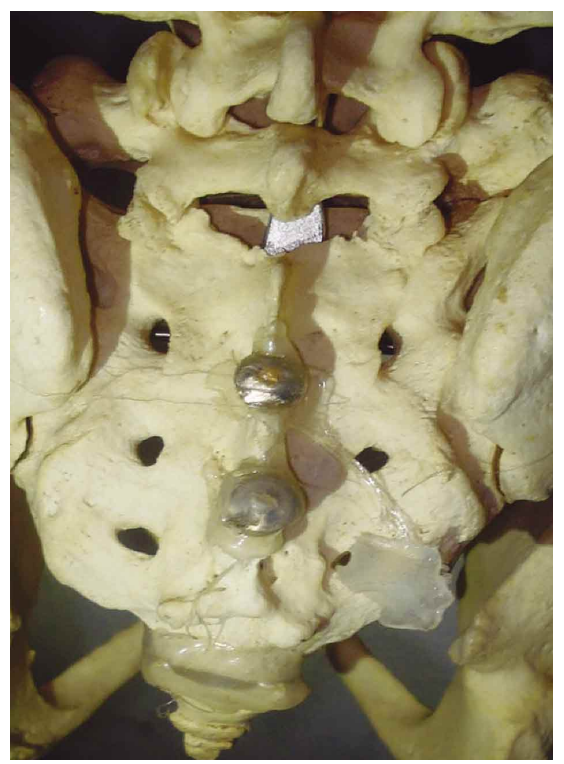

Fig. 2. Dorsal surface of sacrum showing non fusion of lamina of S1 and S2 with distinct disc space between $\mathrm{S} 1$ and $\mathrm{S} 2$, and presence of three distinct dorsal sacral foramina.

\section{DISCUSSION}

The lumbosacral spine not only protects the spinal cord and spinal nerves but also support and transmits weight of the body to the inferior extremity and plays an important important role in posture and locomotion. LSTV are most common congenital anomalies of the lumbosacral spine involving lumbarisation and sacralisation. Complete transition results in numerical abnormalities of the lumbar and sacral segments. In most cases transition is incomplete or unilateral but can also be bilateral and complete. Bron et al. (2007), reported the prevalence of LSTV reported in the literature ranges from 4 to over $35 \%$ which can be explained based on differences in diagnostic criteria, imaging techniques, varied clinical presentation.

In the lumbosacral region, anatomical variations occur frequently, making the sacrum the most variable portion of spine (Williams et al., 1965; Sadler, 2010; Samreen et al., 2012). The variation can be attributed to the dependency of the sacral morphology to the load related fusion of the bone structure as it helps in the transmission of weight to lower extremity. Wellik \& Capecchi (2005) reported Genetic factors have also been implicated in the development if transitional vertebra these include Mutations in the HOX 10 and HOX 11 genes results can alter the normal pattering of lumbar and sacral vertebra leading to lumbosacral transition vertebrae.

Sadler, Breathnach (1965), Hollinshed (1961) and Sharma et al. (2011) reported that vertebrae are developmentally derived from the sclerotomes of the somites. Embryologically, the vertebra during developmental process receives contribution from caudal half of one sclerotome and from the cranial half of succeeding sclerotome. Lumbarisation and sacralisation are caused by the border shifts. Sacralisation of fifth lumbar vertebra is due to cranial shift and the lumbarisation of first sacral segment is due to caudal shift. Breathnach, Hollinshed and Sharma et al., noted ossification defects can potentially lead to development of various vertebral defects but it is very difficult to differentiate between ossification defects and developmental defects as both have same morphological features.

Cheng \& Song (2003) reports lumbarisation of first sacral vertebrae is less common compared to sacralisation of fifth lumbar vertebrae the incidence is very low approximately $2 \%$ of the population. According to Meschan (1985), complete lumbarisation of the first sacral vertebrae leads to increase in the number of lumbar vertebrae which is a very rare occurrence as reported in earlier studies. While partial lumbarisation of sacral vertebrae have been reported with lesser incidence. Partial lumbarisation can been seen with distinct disc space between the $\mathrm{S} 1$ and $\mathrm{S} 2$ or partial fusion between the bodies of $\mathrm{S} 1$ and $\mathrm{S} 2$ with no disc space between them. Lumbarization of the first sacral vertebra refers to the segmentation and incorporation of this vertebra into the lumbar spine.

Khanna \& Chauvan (2003), observed the patients who have three dorsal sacral foramina could present with pain in lower part of the back and legs. If such an anomaly exists then there is all possibility that the fourth sacral nerve roots also passes through the sacral hiatus along with the fifth sacral, coccygeal roots and the filum terminale exiting through it. In that case, any sacrococcygeal tumor may compress upon fourth sacral roots also, leading to neurological involvement of the bladder and rectum also. 
Eyo et al. (2001), opined that high incidence of LSTV in low back pain (LBP) patients suggests that there is a strong relationship between the congenital anomaly LSTV and LBP. Wigh \& Anthony (1981), reported morphologic characteristics of transitional vertebrae include squaring of the upper sacral segment when it is lumbarized and wedging of the lowest lumbar segment when it is sacralised.

Carapuco et al. (2003), Sadler and Wellik et al., showed that vertebral sacralisation can be induced in transgenic mice by Hoxa11 expression. Wellik et al., showed that in the absence of Hox 11 function, sacral vertebrae are not formed and instead these vertebrae assume a lumbar identity. In addition, they showed that in the absence of Hox 10 function, no lumbar vertebrae are formed. Thus, these studies show that the normal patterning of lumbar and sacral vertebrae as well as the changes in the axial pattern, such as LSTV, result from mutations in the Hox-10 and Hox-11 paralogous genes.

CONCLUSION. LSTV is a benign anatomical variation of the lumbosacral spine that is very often encountered by the spinal surgeon. Lumbarisation of first sacral vertebrae is a very rare form of lumbosacral transitional vertebral anomaly necessitating the ability to accurately identify and number the affected segment. Knowledge of the numerous variations within the spine caused by LSTVs will help the radiologist in understanding and recognizing the imaging findings seen in patients with low back pain and a transitional segment. Awareness of such congenital anomaly is important before any spinal surgery in order to avoid incorrect numbering of vertebrae and consequently prevent wrong level spinal surgery. Incorrect numbering of vertebrae can lead to problems with the administration of intradural or epidural anaesthetics. Hence such variations of lumbarisation of first sacral vertebrae should be kept in mind while reporting the CT, MRI films and X-rays for correct clinical and radiological assessment of patients.

ADIBATTI, M. \& ASHA, K. Lumbarización de la primera vertebra sacra: Rara forma de una vertebra de transición lumbosacral. Int. J. Morphol., 33(1):48-50, 2015.

RESUMEN: En la región lumbosacra, las variaciones anatómicas se basan en cambios en el número de las vértebras sacras, ya sea por ausencia de la primera vértebra sacra o por unión de la quinta lumbar o primera vértebra caudal con el sacro. Las vértebras de transición lumbasacra (VTLS) son las anomalías congénitas más frecuentes de la región lumbosacra. La VTLS más común se produce a nivel de la quinta vértebra lumbar, con signos de fusión al sacro, proceso conocido como sacralización; mientras que la primera vértebra sacra también puede mostrar signos de transición a una configuración lumbar. A esto último se lo denomina lumbarización. La transición completa puede provocar anomalías numéricas a nivel de los segmentos vertebrales lumbares y sacros. La lumbarización de la primera vértebra sacra se observa con una incidencia muy baja, de solo $2 \%$. El conocimiento de la presencia de dicha variación vertebral será de utilidad para los médicos al momento de diagnosticar y tratar a los pacientes con dolor en la parte baja de la espalda. Aunque la sacralización de la quinta vértebra lumbar se produce más frecuentemente en comparación con la lumbarización de la primera vértebra sacra, se presenta aquí un caso de lumbarización de la primera vértebra sacra, rara entre las VTLS, y con implicaciones clínicas.

PALABRAS CLAVE: Vértebras; Sacro; Sacralización; Lumbarización; Vértebras de transición.

\section{REFERENCES}

Breathnach, A. S. Frazer's anatomy of the human skeleton. 6th ed. London, Churchill Livingstone, 1965.

Bron, J. L.; van Royen, B. J. \& Wuisman, P. I. The clinical significance of lumbosacral transitional anomalies. Acta Orthop. Belg., 73(6):687-95, 2007.

Carapuco, M.; Nóvoa, A.; Bobola, N. \& Mallo, M. Hox genes specify vertebral types in the presomitic mesoderm. Genes Dev., 19(18):2116-21, 2003.

Cheng, J. S. \& Song, J. K. Anatomy of the sacrum. Neurosurg. Focus, 15(2):E3, 2003.

Eyo, M. U.; Olofin, A.; Noronha, C. \& Okanlawon, A. Incidence of lumbosacral transitional vertebrae in low back pain patients. West Afr. J. Radiol., 8(1):1$6,2001$.

Hollinshead, W. H. Anatomy for Surgeons. The back and limbs. New York, A. Hoeber-Harper, 1961. V. 3. pp.92-119.

Khanna, J. \& Chauvan, R. Anatomical variations and clinical relevance of dorsal sacral foramina in North Indians. Int. J. Res. Med. Sci., 1(3):263-6, 2003.

Meschan, I. An Atlas of Anatomy Basic to Radiology. Philadelphia, W. B. Saunders, 1985. pp.511-2.

Sadler, T. W. Langman's Medical Embryology. 11th ed. Philadelphia, Lippincott Williams \& Wilkins, 2010. pp.142.

Samreen, P.; Shashikala, L. \& Rohini, K. Lumbarization of first sacral vertebra: A case report. Int. J. Basic Appl. Med. Sci., 2(2):154-7, 2012.

Sharma, V. A.; Sharma, D. K. \& Shukla, C. K. Osteogenic study of lumbosacral transitional vertebra in central India region. J. Anat. Soc. India, 60(2):2127, 2011.

Wellik, D. M. \& Capecchi, M. R. Hox10 and Hox11 genes are required to globally pattern the mammalian skeleton. Science, 301(5631):363-7, 2005.

Wigh, R. E. \& Anthony, H. F. Jr. Transitional lumbosacral discs. probability of herniation. Spine (Phila Pa 1976), 6(2):168-71, 1981.

Williams, P. C. The lumbosacral spine, emphasizing conservative management. New York, McGraw-Hill Book Company, 1965. pp.27-32, 149-50.

Correspondence to:

Received: 22-05-2014

Dr. Mallikarjun Adibatti

Accepted: 27-10-2014

Department of Anatomy

ESIC Medical College and PGIMSR

K. K. Nagar Chennai - INDIA

Email: na_mallikarjun@rediffmail.com 